Avalaible online: https://ejournal.iai-tribakti.ac.id/index.php/pgmı Article doi: https://doi.org/10.33367/jiee.v2i1.1041

\title{
Implementasi Aplikasi Rapor Digital Madrasah dalam Penilaian Hasil Belajar Siswa
}

\section{Implementation Of Digital Report Applications Madrasa In Assessment Of Student Learning Outcome}

\author{
1Muhammad Ali Nurdin, ${ }^{2}$ Abdul Halim Mustofa \\ Institut Agama Islam Tribakti Kediri \\ 1nurdynaly245@gmail.com_2abdulhalim.mustofa@gmail.com
}

\begin{abstract}
The use of digital report cards in the Islamic Pramary School 2 Kediri City begins in the 2017-2018. This is driven by the desire of all parties to improve work efficiency. This application makes it easy for teachers to fill in the value of student learning outcomes and archiving. Because it is very new with the experience of new teachers, of course the application of this application has many obstacles. Based on that, this research uses descriptive qualitative research. The selection of qualitative research methods due to the characteristics of this study who want to see the depth, data collection methods using in-depth interviews, observation and reading documents according to the focus of research. This study aims to describe the Implementation of Digital Madrasah Report Card Application in the assessment of student learning outcomes Islamic Pramary School 2 Kediri City. This research is a qualitative case study approach. Data collection techniques carried out by interview, observation, and documentation of the research object. The results of the research show that the process of implementing a digital report card on madrasas in the assessment of student learning outcomes in Islamic Pramary School 2 Kediri City in Kediri is technically in accordance with the guidelines for using the Digital Report Card Application, but the implementation has experienced obstacles so that it has not succeeded in achieving the goal of Madrasa ARD in managing assessment of learning outcomes students quickly, precisely, accurately, effectively and efficiently.
\end{abstract}

Keywords: Madrasah, Digital Report Card Application, Learning Outcomes Assessment

\begin{abstract}
Abstrak
Penggunaan aplikasi rapor digital di Madrasah Ibtidaiyah Negeri (MIN) 2 Kota Kediri di mulai Tahun Ajaran 2017-2018. Hal ini didorong keinginan semua pihak untuk meningkatkan efesiensi
\end{abstract}


kerja. Aplikasi ini mempermudah guru untuk mengisi nilai hasil pembelajaran siswa dan pengarsipan. Karena sangat baru dengan pengalaman guru yang baru, tentu penerapan aplikasi ini mempunyai banyak kendala. Berdasarkan itu, penelitian ini menggunakan penelitian kualitatif-diskriptif. Pemilihan metode penelitian kualitatif disebabkan ciri khas penelitian ini yang ingin melihat kedalaman, Metode pengumpulan data menggunakan wawancara mendalam, observasi dan pembacaan dokumen sesuai fokus penelitian. Penelitian ini bertujuan untuk mendeskripsikan Implementasi Aplikasi Rapor Digital Madrasah dalam penilaian hasil belajar siswa di Madrasah Ibtidaiyah Negeri (MIN) 2 Kota Kediri. Penelitian ini merupakan penelitian kualitatif pendekatan studi kasus. Teknik pengumpulan data dilakukan dengan cara wawancara, observasi, dan dokumentasi terhadap objek penelitian. Hasil penelitian menunjukkan proses pelaksanaan aplikasi rapor digital madrasah dalam penilaian hasil belajar siswa di MIN 2 Kota Kediri secara teknis sudah sesuai dengan panduan penggunaan Aplikasi Raport Digital, akan tetapi dalam pelaksannaanya mengalami kendala-kendala sehingga belum berhasil mencapai tujuan ARD Madrasah dalam pengelolaan penilaian hasil belajar siswa secara cepat, tepat, akurat, efektif dan efisien.

\section{Kata Kunci: Madrasah, Aplikasi Rapor Digital, Penilaian Hasil Belajar}

\section{Pendahuluan}

Penilaian hasil belajar merupakan komponen yang tidak terpisahkan dalam penyelenggaran pendidikan. Keharusan melaksanakan penilaian hasil belajar ditegaskan dalam Peraturan Menteri Pendidikan dan Budaya Nomor 66 Tahun 2013 tentang Standar Penilaian Pendidikan bahwa standar penilaian bertujuan untuk menjamin: (1) Perencanaan peserta didik sesuai dengan kompetensi yang dicapai berdasarkan prinsipprinsip penilaian, (2) Pelaksanaan penilaian peserta didik secara profesional, terbuka, edukatif, efektif, efisien, dan sesuai dengan konteks sosial budaya, serta (3)
Pelaporan hasil penilaian peserta didik secara objektif, akuntebel dan informatif. ${ }^{1}$

Penerapan standar penilaian harus memperhatikan prinsipprinsip penilaian. Menurut. Eko Putro Widoyoko, prinsip-prinsip penilaian mencakup: sahih atau valid, objektif, adil, terpadu, terbuka, menyeluruh dan berkesinambungan, sistematis, ekonomis, akuntabel, dan edukatif. ${ }^{2}$ Prinsip-prinsip ini sesuai dengan standar pengelolaan penilai-

\footnotetext{
1 Permendikbud nomor 66 tahun 2013 tentang Standar Penilaian Pendidikan.

2 Eko Putro Widoyoko, Penilaian Hasil Pembelajaran di Sekolah (Yogyakarta: Pustaka Belajar, 2014), h. 17.
} 
an yang diatur oleh undang-undang. Kelebihan rumusan prinsip-pinsip ini, mampu diterapkan aplikasi internet. Tidak bisa dipungkiri, internet sudah berkembang begitu cepat dan menjadi bagian dari kehidupan masyarakat. Hampir bisa dipastikan semua anggota masyarakat mengenal dunia internet. Hal ini tentu berdampak pada pola perilaku dan cara pandang masyarakat, termasuk dalam dunia pendidikan. Madrasah pun harus mengikuti perkembangan tersebut jika ingin bersaing di era internet. Pasalnya, kecepatan penyebaran informasi terutama bagi siswa Madrasah, untuk mencapai target kinerja sekaligus memenuhi harapan publik yang menuntut adanya keterbukaan informasi.

Harapan publik tidak bisa dipandang sebelah mata. Salah satu indikator, sekolah atau madrasah bermutu adalah keterlibatan publik dalam merespon lembaga pendidikan. Merespon hal ini Kementrian Agama melalui Direktorat Jendral Pendidikan Islam meluncurkan Aplikasi Rapor Digital Madrasah (ARDM) yang diperuntukkan untuk seluruh madrasah swasta atau negeri yang ada di Indonesia. Dengan adanya ARDM bertujuan agar pengelolaan penilaian hasil belajar dapat dilakukan secara cepat, tepat, akurat, efektif, dan efisien.

ARDM merupakan aplikasi pendataan dan administrasi lembaga madrasah secara online yang mengkhususkan dalam digitalisasi dan standardisasi rapor sehingga data rapor peserta didik madrasah seluruh Indonesia tersimpan pada database Kementrian Agama Republik Indonesia. Dengan begitu data dapat dipergunakan sewaktuwaktu dibutuhkan secara cepat, tepat dan akurat. Proses verifikasi pun sangat mudah, dapat dilakukan jarak jauh dengan menggunakan layanan internet.

ARDM merupakan aplikasi rapor yang dioperasikan secara online berbasis Web dan Android, sehingga guru dapat mengelola penilaian hasil belajar kapanpun dan dari manapun. ${ }^{3}$ Di samping itu ARDM juga dapat di operasikan secara offline. Aplikasi offline ini dapat dipergunakan, hingga nanti ketika sudah dapat login ke layanan ARDM tinggal menguploadnya (unggah). Kelebihannya, jika ARDM secara online mengalami kendala, maka bisa beralih ke ARDM Offline.

Sejarah perjalanan perkembangan Aplikasi Rapor Digital (ARD) sangat panjang. Dalam perkembangannya, aplikasi rapor yang berbasis online mulai diterapkan di Indonesia sejak tahun 2013. Nama aplikasi rapor yang berbasis online tersebut adalah Rapor Online, yang digagas oleh Kementrian Pendidikan dan Kebudayaan. Program ini diperuntukkan untuk sekolahsekolah yang berada di bawah naungan Kementrian Pendidikan dan Kebudayaan Republik Indonesia. Sedangkan pada madrasah ada yang namanya ARD Madrasah, yang merupakan aplikasi rapor yang berbasis online yang digagas oleh Kementrian Agama

3 Keputusan Direktur Jenderal Pendidikan Islam nomor 6003 tahun 2018 tentang Juknis Bimtek ARD Madrasah, h. 1. 
yang baru diluncurkan pada Oktober 2018. ${ }^{4}$ Dengan demikian dapat ditarik kesimpulan bahwasanya Rapor Online dan ARDM merupakan aplikasi rapor yang sama-sama berbasis Online. Sedangkan perbedaannya dari keduanya terletak pada penggagas dan ranah penerapannya.

Meskipun begitu lama perkembangan, akan tetapi peneliti bidang pendidikan tidak banyak tertarik meneliti tentang ARD. Rujukan penelitian paling sederhana dilakukan oleh Sri Roekminiati Dosen Studi Universitas Dr. Soetomo Surabaya berjudul "Evaluasi Terhadap Pelayanan Rapor Online di SMP Negeri 12 Surabaya". Hasil penelitian menemukan indeks kepuasan masyarakat terhadap kualitas pelayanan rapor online di SMP Negeri 12 Surabaya adalah 2,89\%, dengan Mutu Pelayanan B ini berarti Baik. ${ }^{5}$

Penelitian ini kemudian ditindaklanjuti dalam kajian skripsi oleh Kevin Bagus Rhesa Firmanda, Program Studi Ilmu Administrasi Negara, Fakultas Ilmu Sosial dan Hukum, Universitas Negeri Surabaya (UNS) yang berjudul penelitian “ Implementasi Program Rapor Online di SMK Negeri 1 Surabaya". Hasil penelitian-nya menunjukkan bahwa implementasi program rapor online di SMK Negeri 1 Surabaya sudah berjalan baik namun masih terdapat

4 Kemdikbud . 2017. Panduan Penggunaan erapor 2017. Online. http//psma.kemdikbud.go.id/.diakses 22 Juli 2019.

${ }^{5}$ Sri Roekminiati, Evaluasi terhadap Pelayanan Rapor Online di SMP Negeri 12 Surabaya, (Surabaya, UNS), h. 22 beberapa kendala. Kendala yang dihadapi dari indikator komunikasi adalah kurang jelasnya penyampaian informasi mengenai kebijakan. ${ }^{6}$

Berdasarkan itu semua, peneliti melakukan penelitian tentang Implementasi ARDM dalam penilaian Hasil Belajar Siswa di Madrasah Ibtidaiyah Negeri (MIN) 2 Kota Kediri. Pemilihan tema ini mempunyai dua alasan kuat, pertama secara akademik, tidak banyak peneliti yang mengambil tema tersebut, dan kedua, karena MIN 2 Kota Kediri sudah menerapkan rapor digital sejak tahun pelajaran 2018/2019. Waktu yang singkat ini sangat menarik karena MIN 2 Kota Kediri menjadi rujukan penerapan ARD di sekolah-sekolah se-Kota Kediri. Sesuai dengan alasan tersebut, maka peneliti berfokus untuk mencari jawaban tentang: [1] proses pelakasanaan aplikasi rapor digital madrasah dalam penilaian hasil belajar siswa di MIN 2 Kota Kediri dan [2] Refleksi implementasi aplikasi rapor digital madrasah dalam penilaian hasil belajar siswa di MIN 2 Kota Kediri.

\section{Metode Penelitian}

Penelitian ini merupakan penelitian kualitatif - deskriptif. Penelitian kualitatif merupakan penelitian yang menghasilkan data deskripsi berupa kata-kata tertulis atau lisan dan perilaku orang-orang

6 Kevin Bagus Rhesa Firmanda, Universitas Negeri Surabaya (UNS) yang berjudul penelitian" Implementasi Program Rapor Online di SMK Negeri 1 Surabaya" diakses 22 Juli 2019 
yang diamati secara mendalam,sadar dan terkenali. Dengan demikian penelitian deskriptif kualitatif ini adalah mendeskripsikan proses pelaksanaan Aplikasi Rapor Digital Madrasah dalam penilaian hasil belajar siswa di MIN 2 Kota Kediri.

Teknik pengumpulan data yang dilakukan dengan cara wawancara, observasi, dan dokumentasi. Sedangkan waktu yang digunakan peneliti mulai 1 Maret-1 Juni 2019. Data yang sudah terkumpul dianalisis secara berulang dengan melakukan reduksi, penyajian data dan penarikan kesimpulan atau verifikasi. Untuk meningkatkan kepercayaan hasil penelitian maka dilakukan pengecekan keabsahan data dengan cara triangulasi data.

\section{Hasil Dan Pembahasan}

Dari segi manajemen pendidikan maka pelaksanaan ARDM dibagi menjadi 3 bentuk yaitu, perencanaan, pelaksanaan dan evaluasi.

\section{Tahap Perencanaan}

Sebelum membahas perencanaan ARDM dalam penilaian hasil belajar siswa di MIN 2 Kota Kediri, kita ketahui terlebih dahulu perencanaan penilaian hasil belajar. Perencanaan penilaian tersebut tertuang dalam Buku Kurikulum MIN 2 Kota Kediri yakni, perencanaannya diawali dengan membuat Jadwal Penilaian Tengah Semester (PTS), Penilaian Akhir Semester (PAS)/ Ujian Kenaikkan Kelas (UKK), Silabus, Rencana Pelaksanaan Pembelajaran (RPP), dan perumusan prinsip-prinsip penilaian. Buku
Kurikulum tersebut sebagai perencanaan penilaian hasil belajar siswa sudah tertulis adanya penilaian sikap, pengetahuan dan keterampilan. Hal tersebut sesuai dengan Standar penilaian pendidikan pada poin pertama bahwa perencanaan peserta didik sesuai dengan kompetensi yang dicapai berdasarkan prinsip - prinsip penilaian. ${ }^{7}$

Perencanaan ARD Madrasah di MIN 2 Kota Kediri diawali dengan mengirimkan delegasi ke Kemenag Kota Kediri guna mengikuti sosialisasi ARD. Delegasi yang dikirim adalah Kepala Madrasah dan Staf Operetor Madrasah. Pemilihan delegasi tersebut sesuai surat undangan dari Kemenag Kota kediri. Kemudian Kepala Madrasah menyampaikan kepada seluruh guru bahwa ada kebijakan dari kemenag untuk menggunakan ARD dalam penilaiaan hasil belajar. Operator melakukan sosialisasi kepada seluruh wali kelas dan guru mata pelajaran (mapel) yang ada di MIN 2 Kota Kediri. Adapun materi sosialisasi tersebut berkaitan dengan tugas wali kelas dan guru mapel serta prosedur penggunaan ARD Madrasah. Pengiriman delegasi dari MIN 2 Kota Kediri untuk menghadiri sosialisasi ARD Madrasah di Kantor Kemenag Kota Kediri merupakan tindak lanjut dari Surat Edaran Direktorat Jendral Pendidikan Islam Kementrian Agama Nomor 1594/DJ.II.I /KS00/10/2018) tentang ARDM

\footnotetext{
7 Permendikbud nomor 66 tahun 2013 tentang Standar Penilaian Pendidikan.
} 
tepatnya pada bagian kedua yaitu Kanwil Kemenag Provinsi untuk melakukan sosialisasi kepada Kemenag Kabupaten / Kota dan madrasah di wilayahnya. ${ }^{8}$

\section{Tahap Pelaksanaan.}

Penerapan ARD madrasah dalam penilaian hasil belajar siswa di MIN 2 Kota Kediri dimulai pada semester ganjil tahun pelajaran 2018-2019. Artinya MIN 2 Kota Kediri baru pertama kali ini menerapkan ARD Madrasah dan pada semester genap tahun pelajaran 2018-2019 ini memasuki periode kedua. Hal ini sesuai dengan instruksi Kemenag dalam Surat Edaran Direktorat Jendral Pendidikan Islam Kementrian Agama Nomor 1594/DJ.II.I/KS00/10/2018) yaitu ARDM diterapkan mulai semester ganjil tahun pelajaran 2018/2019.9

Pelaksanaan ARD Madrasah di MIN 2 Kota Kediri dilakukan wali kelas dan guru mata pelajaran (mapel) serta operator menjadi pengguna dalam ARDM. Sebagaimana yang disebutkan dalam Panduan Penggunaan ARD (untuk operator dan guru madrasah ibtidaiyyah) bahwa tingkat madrasah, pengguna Aplikasi Rapor Digital Madrasah dibedakan menjadi dua

8 Surat Edaran Direktorat Jendral Pendidikan Islam Kementrian Agama Nomor 1594/DJ.II.I/KS00/10/2018) tentang ARD Madrasah

9 Surat Edaran Direktorat Jendral Pendidikan Islam Kementrian Agama Nomor 1594/DJ.II.I/KS00/10/2018) tentang ARD Madrasah jenis, yaitu Akun Operator Madrasah dan Akun Guru. ${ }^{10}$

Tugas wali kelas, guru mata pelajaran (mapel) dan operator itu tidak sama. Dengan ketidaksamaan tugas tersebut maka dapat melengkapi satu sama lain sehingga memperlancar jalannya ARD dalam penilaian hasil belajar siswa di MIN 2 Kota Kediri. Mereka menjalankan ARD sesuai dengan tugasnya masing-masing. Hal tersebut senada dengan apa yang di sampaikan oleh al moon bahwa dengan masingmasing pihak memahami tugas, tanggung jawab, prosedur, dan tata cara dalam mengerjakan Aplikasi Rapor Digital Madrasah diharapkan beban pekerjaan tidak hanya ditimpakan kepada operator madrasah saja. Namun dapat dibagi kepada masing-masing guru pelajaran, dan wali kelas. Sehingga pengerjaan ARD Madrasah akan semakin ringan dan akuntabel.11

Tugas-tugas yang diemban oleh para guru mata pelajaran (mapel), wali kelas dan operator yang ada di MIN 2 Kota Kediri sudah sesuai dengan apa yang ada di buku panduan pengerjaaan ARD Madrasah. ${ }^{12}$ Namun, tugas mencetak rapor yang seharusnya dipegang oleh wali

10 Panduan Penggunaan Aplikasi Raport Digital (Untuk Operator Madrasah dan Guru Madrasah Ibtidaiyyah.

11 Al Moon,"Panduan Mengerjakan Aplikasi Rapor Digital (ARD) Madrasah", https://ayomadrasah.blogspot.com/2018/ 10/panduan-aplikasi-ard-madrasah.html, 30 Oktober 2018, di akses tanggal 26 Januari 2019.

12 Panduan Penggunaan Aplikasi Raport Digital (untuk operator madrasah dan guru madrasah ibtidaiyyah.. 
kelas, dilimpahkan kepada waka kurikulum untuk dicetakkan melalui jasa percetakan. Akan tetapi wali kelas terlebih dahulu memberikan flash disk yang berisi rapor yang sudah siap dicetak. Di dalam Juknis Bimtek ARD Madrasah dijelaskan bahwasanya ARD Madrasah dapat dioperasikan secara online berbasis Web dan Android, sehingga guru dapat mengelola penilaian hasil belajar kapan saja dan dari mana saja. ${ }^{13}$

Akan tetapi, dalam pelaksanaannya di MIN 2 Kota Kediri, proses penggunaan dan penginputan nilai hanya bisa dilakukan di madrasah saja, tidak bisa dikerjakan di rumah ataupun dimanapun tempat sesuai dengan kesiapan dari para guru. Menurut peneliti, jika pengerjaan ARD hanya bisa dilakukan saat di Madrasah, maka tentu lebih memberatkan tugas guru saat di madrasah. Tidak hanya melakukan KBM, akan tetapi juga harus menyelesaikan laporan hasil penilaian saat di madrasah pula.

Jika pengerjaan ARD bisa dilakukan di rumah atau dimanapun, tentu ini (ARD) dapat dikatakan sangat meringankan dan memudahkan bagi guru. Namun yang terjadi di MIN 2 Kota Kediri tidak sesuai dengan apa yang diutarakan peneliti. Hal tersebut terjadi demikian karena penggunaan ARD Madrasah harus satu wifi, lapotp server harus nyala dan tidak bisa jauh dengan laptop server.

13 Keputusan Direktur Jenderal Pendidikan Islam nomor 6003 tahun 2018 tentang Juknis Bimtek ARD Madrasah, h. 1.
ARDM dapat dioperasikan secara online berbasis Web dan Android. Padahal di samping itu ARDM juga dapat di operasikan secara offline. Akan tetapi, ARDM yang digunakan di MIN 2 Kota Kediri hanya ARDM yang berbasis online, sedangkan ARD Madrasah yang berbasis offline belum digunakan. Padahal dalam proses penggunaannya sering kali guru mengalami gangguan teknis tidak bisa login ke sistem ARD. Artinya apa yang telas dilakukan tersebut belum sesuai dengan seperti yang di katakan oleh admid ayo madrasah bahwa:

"Bagi madrasah yang tidak bisa login ke ARD Madrasah, di sarankan untuk menggunakan ARD Madrasah versi offline. Sebelum menggunakannya, tentu harus men-download aplikasi ARD Madrasah Offline terlebih dahulu. Dan per-6 Desember 2018, Dirjen Pendis akhirnya merilis aplikasi offline ARD Madrasah". ${ }^{14}$

Menurut peneliti, jika MIN 2 Kota Kediri menerapkan pula ARD Madrasah yang berbasis offline, maka proses penginputan nilai yang dilakukan oleh guru tidak terganggu. Hal ini tentu sangat membantu, manakala proses penginputan nilai pada ARD Madrasah berbasis offlne sudah selesai, maka tinggal

14 admin ayo madrasah, "Download ARD Madrasah Versi Offline [Link Alternatif]", https://ayomadrasah.blogspot.com/2018/ 12/download-ard-madrasah-versioffline.html, 06 Desember 2018. diakses 15 April 2019. 
menguploadnya (unggah) ke ARDM secara online.

ARDM bertujuan agar pengelolaan penilaian hasil belajar dapat dilakukan secara cepat, tepat, akurat, efektif, dan efisien. ${ }^{15}$ Akan tetapi, jika berkaca dari pelaksanaan ARD Madrasah di MIN 2 Kota Kediri, tujuan tersebut belum seluruhnya berhasil dicapai. Berdasarkan analisis dari peneliti, didalam ARD sudah tepat dan akurat untuk memberikan informasi hasil belajar siswa yang meliputi aspek pengetahuan, sikap dan keterampilan yang disertai dengan nilai dan deskripsi.

Namun, ARD belum bisa berjalan secara cepat, efektif dan efisien. Karena dalam pelaksanaannya banyak tahapan-tahapan yang harus dilalui oleh guru, penginputan nilai dan deskripsi dilakukan secara manual serta membutuhkan waktu yang lama untuk menyelesaikannya. Selain itu, ARD juga belum bisa memenuhi harapan Kemenag Pusat agar data rapor peserta didik seluruh indonesia dapat di pergunakan sewaktu-waktu secara cepat, karena ARD di MIN 2 Kota Kediri yang mengalami keterlambatan dalam menyelesaikan rapor ARD semester ganjil tahun ajaran 2018-2019.

Rapor yang seharusnya diselesaikan pada bulan Desember 2018, akan tetapi baru dapat di selesaikan pada semester genap tahun 2019 tepatnya pada bulan Maret. Itu artinya MIN 2 Kota Kediri mengalami keterlambatan kurang

15 Keputusan Direktur Jenderal Pendidikan Islam nomor 6003 tahun 2018 tentang Juknis Bimtek ARD Madrasah, h. 1. lebih 3 bulan yang terhitung mulai bulan Januari, Februari dan Maret.

\section{Tahap Evaluasi}

Setelah peneliti mengetahui perencanaan dan pelaksanaan ARD madrasah dalam penilaian hasil belajar siswa di MIN 2 Kota Kediri, maka selanjutnya peneliti menggali informasi lebih dalam lagi terkait dengan evaluasi dari penggunaan ARD Madrasah di MIN 2 Kota Kediri.

Secara umum aplikasi ini memang sedikit membantu memudahkan operator dalam print out hasil belajar peserta didik, bukan hanya kuantitas nilai saja yang tercantum, akan tetapi di dalamnya tertulis juga deskripsi nilai pengetahuan dan pemahaman siswa, kemampuan - kemampuan serta keterampilan siswa semua tercantum secara detail pada setiap lini mata pelajaran, sehingga ketika penerimaan raport orangtua akan tahu sejauh mana hasil belajar anak selama satu semester.

MIN 2 Kota Kediri sudah berhasil menerapkan ARD Madrasah pada semester ganjil tahun ajaran 2018-2019. Padahal baru periode pertama menerapkan ARDM. Namun, dibalik keberhasilan tersebut, tidak terlepas dari kendala atau hambatan, baik yang dialami oleh guru maupun operator. Adapun kendala-kendala tersebut akan dijelaskan sebagaimana berikut.

a. Jangkauan dan kecepatan jaringan Internet (wifi) masih sangat terbatas.

b. Terkadang masih mengalami trouble dengan jaringan 
internet atau server yang tidak conect.

c. Input deskripsi yang serba manual

d. Patching raport yang berbedabeda pada setiap komponen.

e. Harus terhubung dalam satu jaringan wifi dengan komputer/laptop yang terinstal ARD Madrasah.

f. Terbatas dengan tempat dan waktu, sehingga ARD Madrasah hanya bisa dioperasikan pada saat di madrasah.

g. Penyelesaian input data belum bisa terselesaikan pada saat yang bersamaan. Masih ada guru mapel ataupun yangb belum menginput data, sehingga pada saat waktunya untuk mencetak rapor belum bisa dilakukan.

Meskipun MIN 2 Kota Kediri berhasil menyelesaikan rapor ARD untuk semester ganjil, akan tetapi dari segi waktu tergolong terlambat. Idealnya rapor semester ganjil di kerjakan dan dibagikan ke wali murid juga pada semester ganjil. Sedangkan di MIN 2 Kota Kediri rapor ARD semester ganjil baru bisa dikerjakan di semester genap.

Walapun terlambat, pengerjaan rapor ARD tetap dikerjakan karena ada tuntutan dari kemenag untuk menyelesaikan rapor ARD, kemudian di kirim ke pusat sebagaimana yang telas tercantum dalam surat dari kemenag pusat. Jadi, ARD hanya sebagai formalitas, sebagai- mana lembaga madrasah negeri harus tunduk dan patuh atas kebijakan Kemenag.

Kemudian untuk rapor ARD semester genap tahun ajaran 20182019 sampai peneliti melakukan penelitian ini tidak ada aktivitas apapun sebagaimana dalam pengerjaan ARD pada rapot semester ganjil. Hal tersebut terjadi karena belum ada informasi dari kemenag untuk melanjutkan ARD di semester genap ini. Selanjutnya, dalam menyingkapi hasil evaluasi terhadap proses pelaksanaan ARD Madrasah dalam penilaian hasil belajar di MIN 2 Kota Kediri, peneliti menilai bahwa kekurangan, kelebihan dan kendala yang dialami selama pelaksanaan ARD.

Hal itu menjadi sesuatu yang dapat dimaklumi, mengingat ARD madrasah masih dalam taraf uji coba dan juga masih periode pertama di MIN 2 Kota Kediri. Maka, untuk pelaksanaan ARD pada periode selanjutnya harus adanya perbaikanperbaikkan yang dilakukan oleh MIN 2 Kota Kediri.

4. Analisis penerapan Aplikasi Rapor Digital Madrasah dalam penilaian hasil belajar siswa di MIN 2 Kota Kediri.

Dalam pembahasan pada sub bab ini akan di paparkan bagaimana refleksi ataupun tindak lanjut dari hasil evaluasi yang dilakukan oleh MIN 2 Kota Kediri terkait dengan pelaksanaan ARD Madrasah dalam penilaian hasil belajar siswa. Dari hasil evaluasi tersebut di temukan bahwa dalam proses pelaksanaan ARD Madrasah ditemukan beberapa 
kendala. Kendala-kendala tersebut menjadi penghambat dalam proses pelaksanaan ARD Madrasah maupun tujuan dari ARD madrasah. Maka, untuk menghadapi kendala tersebut pihak MIN 2 Kota Kediri melakukan beberapa tindakan diantara:

a. Menambah jangkauan dan kecepatan jaringan internet (wifi).

b. Laptop operator terus dihidupkan selama guru mengerjakan ARD madrasah, yakni mulai pukul 07.00 15.00 WIB. Karena para guru mengerjakan ARD disela-sela waktu sibuks, tepatnya ketika jam istirahat dan setelah peserta didik pulang sampai jam kerja guru usai $(15.00$ WIB).

c. Waka kurikulum memberikan waktu maksimal penyetoran rapor ARD sebelum masuk pada tahap pencetakan. Tujuannya adalah supaya para guru lebih giat untuk menyelesaikan laporan sesuai batas waktu yang telah ditentukan.

d. Para wali kelas secara intensif melakukan pengecekan nilai rapor yang belum di input. Biasanya ada guru mapel yang lupa belum memasukan nilai. Dengan adanya pengecekan yang dilakukan oleh walikelas maka bisa meminimalisir adanya kelambatan dalam proses penyelesaian rapor.
Refleksi ataupun tindak lanjut dari hasil evaluasi yang dilakukan oleh MIN 2 Kota Kediri terkait dengan pelaksanaan ARD Madrasah dalam penilaian hasil belajar siswa sangat penting untuk dilakukan. Dengan adanya refleksi tersebut dapat membuat pelaksanaan ARD menjadi lebih baik.

Terkait dengan kendala teknis yang dialami oleh para guru dalam penggunaan ARD sudah dilakukan perbaikkan sebagaimana yang telah dipaparkan sebelumnya juga oleh peneliti. Sedangkan ketika belum ada kepastian ARD semester genap dari kemenag, maka pihak madrasah memilih untuk tetap membuat rapor dengan aplikasi lain yaitu aplikasi aerobi. Ini merupakan sebuah keputusan terbaik yang telah diambil oleh pihak madrasah. Mengingat laporan hasil penilaian merupakan suatu hal yang harus dilakukan oleh guru setelah melakukan KBM.

Sebagaimana yang diungkapkan oleh teguh triwiyanto, "rapor merupakan dokumen yang menjadi penghubung komunikasi baik antara sekolah dengan orang tua peserta didik maupun dengan pihak-pihak lain yang ingin mengetahui tentang hasil belajar anak dalam kurun waktu tertentu". Jika, rapor tersebut tidak dibuat maka hubungan antara pihak madrasah dengan wali murid atau dengan pihak lainnya akan terputus.

Kemudian, jika dikemudian hari ada instruksi dari kemenag untuk melanjutkan rapor ARD untuk semester genap tahun ajaran 20182019, maka pihak madrasah akan 
mengerjakannya di semester ganjil tahun ajaran 2019-2020. Hal tersebut dilakukan mengingat waktu yang tersisa untuk semester genap ini hanya menyisakan waktu kurang lebih dua bulan. Yang mana waktu tersebut digunakan untuk Penilaian Akhir Semester (PAS) dan pembuatan rapor untuk format aerobi yang dinilai sangat realistis untuk menyelesaikan rapor dengan sisa waktu yang ada.

\section{Kesimpulan}

Berdasarkan hasil kajian dan penelitian ini, peneliti dapat menyimpulkan bahwa:

Pertama, proses pelaksanaan aplikasi rapor digital madrasah dalam penilaian hasil belajar siswa di MIN 2 Kota Kediri secara teknis sudah sesuai dengan panduan penggunaan Aplikasi Raport Digital, akan tetapi dalam pelaksannaanya mengalami kendala-kendala sehingga belum berhasil mencapai tujuan ARD Madrasah dalam pengelolaan penilaian hasil belajar siswa secara cepat, tepat, akurat, efektif dan efisien.

Kedua, diperlukan usaha untuk mengembangkan kemampuan Sumber Daya Manusia MIN 2 Kota Kediri tentang Aplikasi Raport Digital dan dunia internet.

\section{Daftar Pustaka}

Indrakusuma, Amir. Pengantar Ilmu Pendidikan, Surabaya: Usaha Nasional, 1973.

Admin ayo madrasah, "Download ARD Madrasah Versi Offline
[Link Alternatif]", https://ayomadrasah.blogspot. com/2018/12/download-ardmadrasah-versi-offline.html, 06 desember 2018. diakses 15 april 2019.

Al Moon,"Panduan Mengerjakan Aplikasi Rapor Digital (ARD) Madrasah",

https://ayomadrasah.blogspot. com/2018/10/panduanaplikasi-ard-madrasah.html, 30 Oktober 2018, di akses tanggal 26 Januari 2019.

Diryanto, Administrasi Pendidikan Jakarta: PT Rineka Cipta, 1998. Dewe John, Rapor Digital Madrasah (ARD Madrasahku), https://www.silabus.web.id/ar d-madrasahku/ diakses tanggal 25 Januari 2019.

E. Mulyasa, Manajemen Berbasis Sekolah, Cet.X Bandung: PT Remaja Rosdakarya, 2006.3

Keputusan Direktur Jenderal Pendidikan Islam nomor 6003 tahun 2018 tentang Juknis Bimtek ARD Madrasah.

Panduan Penggunaan Aplikasi Raport Digital (untuk operator madrasah dan guru madrasah ibtidaiyyah..

Permendikbud nomor 66 tahun 2013 tentang Standar Penilaian Pendidikan.

Surat Edaran Direktorat Jendral Pendidikan Islam Kementrian Agama Nomor 
1594/DJ.II.I/KS00/10/2018)

tentang ARD Madrasah.

Widoyoko, Eko Putro. Penilaian Hasil

Pembelajaran di Sekolah.

Yogyakarta: Pustaka Belajar, 2014. 